\title{
Further Comprehension of Social and Historical Background of Institutional Reform of Party and State
}

\author{
Deming Lang \\ School of Marxism \\ Northwest Normal University \\ Lanzhou, China 730070
}

\begin{abstract}
Deepening the institutional reform of the party and state is a profound change in advancing the modernization of the state governance system and governance capacity, and is a major political task that affects the overall situation of the party and the state. Only by profoundly understanding and accurately grasping the new historical orientation of China's development, the historical mission of the Communist Party of China in the new era, the major contradictions in China's society, and social and historical backgrounds such as comprehensively deepening of reforms can we adopt more effective, pragmatic and effective measures, and thereby to improve the scientific level of institutional setting of party and state, optimize the institutional functions of the party and state, continuously promote the institutional reform of the party and state, and take the path of socialist political development with Chinese characteristics.
\end{abstract}

Keywords-party and state; institutional reform; social historical background

\section{INTRODUCTION}

Since the implementation of the reform and opening up policy in 1978, China has made tremendous achievements in its development. The people's living standards have been greatly improved, the economic aggregate has grown steadily, and the country's comprehensive strength has grown stronger. It has become the world's second largest economic system. After 40 years of development of reform and opening up, the main contradiction in Chinese society has been transformed into a contradiction between the people's growing need for a better life and the development of an inadequate balance. Along with the gradual deepening of economic system reform, political system reform has also been promoted in an orderly manner, and has achieved fruitful results. However, very few people ignore the achievements of China's political system reform, think that China's political system reform is seriously lagging behind, and regard the political system of Western countries as a standard, and use this as the direction of China's political system reform to measure the effectiveness of China's political system reform. This is completely wrong and extremely dangerous. Because "there is no identical political system model in the world, the political system cannot be abstractly criticized from specific social and political conditions and historical and cultural traditions. It cannot be considered that only one model is correct and cannot mechanically borrow models of foreign political systems." ${ }^{1}$
The Third Plenary Session of the 19th CPC Central Committee focused on the institutional reform of the party and state, made a top-level design for the institutional reform of the party and state, and made a comprehensive and systematic scientific design of the direction and objectives of the reform. The "Deepening the Party and State Institutional Reform Program" is an implementation plan for the concrete implementation of party and state institutional reforms. Judging from its content, the Party Central Committee has carried out the institutional reform of the party and state with great intensity, wide influence, wide coverage, and complex interests, which have never been seen since the reform and opening up. It is a systematic, holistic, and refactoring change. A correct understanding of the profound social and historical background of party and state institutional reforms is of great significance for the smooth advancement of party and state institutional reform measures and the achievement of reform goals.

\section{DEEPENING THE INSTITUTIONAL REFORM OF THE}

PARTY AND STATE IS AN INEVITABLE REQUIREMENT FOR ADAPTING TO THE NEW HISTORICAL ORIENTATION OF CHINA'S DEVELOPMENT

Since the 18th National Congress of the Communist Party of China, the Party Central Committee with Comrade Xi Jinping as the core has focused on improving and developing the socialist system with Chinese characteristics and promoting the overall goal of modernizing the national governance system and governance capacity, strengthening party leadership, persisting in problem orientation, highlighting key areas, and comprehensively deepening reforms. The socialist system with Chinese characteristics has been further improved, the level of modernization of the state governance system and governance capacity has been greatly improved, and the development and innovation vitality of the whole society have been significantly enhanced. It has provided a strong guarantee for the historic achievements and historic changes of the party and state undertakings. Socialism with Chinese characteristics has entered a new era. This is a new historical orientation for China's development. The report of the 19th National Congress of the Communist Party of China renewed its efforts in comprehensively deepening reforms. It pointed out that "We must persist in and continuously develop China's socialist democratic politics, actively and steadily push forward the reform of the political 
system, and promote the institutionalization, standardization, and proceduralization of socialist democratic politics. Ensure that the people manage state affairs, economic and cultural affairs and social affairs through various channels and forms in accordance with the law, and consolidate and develop a lively, stable and united political situation." 2 The historical changes in the cause of the party and the state objectively require that the institutional functions, setup, and operation of the party and state must better serve the development of the party and the state. Therefore, the institutional reform of the party and state is an inevitable requirement for adapting to the new historical orientation of China's development.

\section{DEEPENING THE INSTITUTIONAL REFORM OF THE}

PARTY AND STATE IS AN INEVITABLE REQUIREMENT FOR THE COMPLETION OF THE HISTORICAL MISSION OF THE

\section{COMMUNIST PARTY OF CHINA IN THE NEW ERA}

General Secretary Xi Jinping pointed out in the report of the 19th National Congress of the Communist Party of China: "To realize the great rejuvenation of the Chinese nation is the greatest dream of the Chinese nation since modern times." ${ }^{3}$ "Today, we are closer, more confident and capable of achieving the goal of the great rejuvenation of the Chinese nation than at any time in history." 4 It is not easy to achieve "the great rejuvenation of the Chinese nation. The whole party must be prepared to make more difficult and harder efforts." We should carry out great struggles, build great projects, and advance great undertakings; and carry out great struggles, build great projects, advance great undertakings, and realize great dreams objectively require us to deepen the institutional reform of the party and state and provide guarantees for the realization of great dreams with a set of reform measures. Therefore, deepening the institutional reform of the party and state is an inevitable requirement for upholding and developing the great cause of socialism with Chinese characteristics, and is also an inevitable requirement for strengthening the party's long-term governance capability. It is also an inevitable requirement for the self-improvement and self-development of the socialist system. It is an inevitable requirement for realizing the goal of two hundred years of struggle, building a socialist modernized country, and realizing the great rejuvenation of the Chinese nation. In other words, in terms of necessity, if we want to build a socialist modernization power in 2050 and realize the Chinese dream of the great rejuvenation of the Chinese nation, we must further improve the national governance system, promote the modernization of state governance capabilities, and take the socialism political development path with Chinese characteristics, constantly optimizes the institutional functions of the party and state, enhances the effectiveness of the party and state institutions, and improves the institutional scientific and standardized levels of the party and state.

\section{DEEPENING THE INSTITUTIONALREFORM OF THE PARTY AND STATE IS AN INEVITABLE REQUIREMENT FOR ADAPTING TO THE MAJOR CONTRADICTIONS IN CHINESE SOCIETY}

The report of the 19th National Congress of the Communist Party of China pointed out that "socialism with Chinese characteristics has entered a new era, and the main contradictions in Chinese society have been transformed into contradictions between the people's growing need for a better life and the inadequate and unbalanced development." 6 However, we must "recognize that the changes of the major contradictions in Chinese society are historical changes will influence the overall situation and put forward many new requirements for the work of the party and the state." 7 Changes in major social contradictions require not only the party and the state to meet the growing needs of the people in economic, political, cultural, social, and ecological aspects, but also to work hard in democracy, the rule of law, fairness, justice, security, and the environment. In particular, it is required to work hard to resolve imbalances and insufficient development, work hard to promote overall social progress and comprehensive development of people, work hard to provide more public goods and public services, and work hard to enhance public service functions and provide public services. Therefore, the institutional reform of the party and state is an inevitable move to actively respond to changes in the main contradictions of society.

\section{DEEPENING THE INSTITUTIONAL REFORM OF THE \\ PARTY AND STATE IS AN INEVITABLE REQUIREMENT FOR COMPREHENSIVELY DEEPENING REFORMS}

Political system reform is a self-revolution of the party. It must undergo profound changes in the field of superstructures to better meet the requirements of the development of economic foundation and productivity. Since 1982, China has continued to reform seven government agencies with the aim of streamlining institutions and improving efficiency. This has enabled the national institutions to continuously optimize their functions and operate increasingly standardized, greatly improving the efficiency of the government and basically realizing the original intention and expected of the reform. This is in line with China's economic system reform and the expectations of the people. However, the requirements of goal of the development of socialism with Chinese characteristics in the new era, comprehensively promoting the overall layout of the "five in one" and coordinately advancing the strategic layout of the "four comprehensive", improving the socialist market economic system, and realizing the modernization of the national governance system and governance capacity are not fully adapted to the party and state institutions. The main performances are as follows: First, in some areas, the party's institutional setup and functional allocation are not sound enough. The system and mechanism for safeguarding the party's overall leadership and promoting the comprehensive and strict governance of the party need to be further improved. For example, before the 19th National Congress of the Communist Party of China, the monitoring mechanism of China was not sound enough to fully meet the requirements of comprehensively and strictly administering the party. In some areas, the overlapping of party and government organizations, the overlapping functions, and the disjunction between power and responsibility were more prominent. Second, the problem of the establishment of government agencies and the division of responsibilities is not scientific, the lack of responsibilities or the lack of efficiency is highlighted, and the transformation of government functions is not in place. Third, there are some areas where the central and local institutions are set to respond to each other. They are highly similar, the upper and 
lower are generally rough, and the problems of unreasonable division of powers and responsibilities are more prominent. The establishment of grassroots institutions and the allocation of power need to be further improved. The ability to organize the masses and serve the masses needs to be further improved. In actual work, the organization setting is not based on the actual situation of the region or the department, but mechanically emphasizes the upper and lower correspondence, and does not understand the flexibility. Fourth, the level of integration of military and civilian development needs to be improved, and the political, advanced, and mass nature of group organizations needs to be enhanced. The problems of inaccurate positioning, unclear functions and low efficiency of institutions are still existed. In some areas of power operation, the constraints and supervision mechanisms are imperfect, and abuse of power, power for personal gain, and power rent-seeking still exist. The scientific, standardized and statutory establishment of the organization is relatively lagging behind, and the organization management method needs to be improved. Therefore, it is necessary to adapt to the requirements of the development of socialism with Chinese characteristics in the new era and deepen the institutional reform of the party and state. Since the 18th National Congress of the Communist Party of China, the Party Central Committee has made tremendous efforts, made breakthroughs and deepened its progress with full courage, and comprehensively promoted deepening reforms. Focus on enhancing the systemic, holistic and synergistic nature of the reform, and making significant progress in some important areas and key links. At present, the reform has entered the deep-water zone and the critical period. The more difficult the task of reform is, the more difficult it is to solve. 2018 coincides with the 40th anniversary of reform and opening up. We must coordinate and advance with the greater political courage and wisdom with the confidence and determination to start from reform and opening up. Break through the shackles of ideological concepts, break through the barriers of solidification of interests, comprehensively deepen reforms in various fields, focus on solving various complex problems and difficult problems, and use all methods to carry out reforms to the end. The institutional reform of the party and state is the key content of the political system reform. We must work hard to improve the scientific level of party and state institutions and optimize the functions of the party and state institutions. We will promote the institutional reform of the party and state with more effective, pragmatic and effective measures, promote the modernization of the national governance system and governance capacity, and take the path of socialist political development with Chinese characteristics.

\section{CONCLUSION}

Deepening the institutional reform of the party and state is a profound change in advancing the modernization of the governance system and governance capacity, and is a major political task that affects the overall situation of the party and the state. ${ }^{8}$ Only by profoundly understanding and accurately grasping the new historical orientation of China's development, the historical mission of the Communist Party of China in the new era, the major contradictions in China, and the history background of comprehensively deepening the reforms, can we continue to advance the institutional reform of party and state through practical measures, improving the scientific level of party and state institutions, optimizing the functions of the party and state institutions, deepening the reform of the political system, and taking the path of socialist political development with Chinese characteristics.

\section{REFERENCES}

[1] Xi Jinping: "Decisive victory to build a well-off society in an all-round way to win a great victory in socialism with Chinese characteristics in the new era - Report at the 19th National Congress of the Communist Party of China", People's Publishing House, March 2018, p. 36.

[2] Xi Jinping: "Decisive victory to build a well-off society in an all-round way to win a great victory in socialism with Chinese characteristics in the new era - Report at the 19th National Congress of the Communist Party of China", People's Publishing House, March 2018, p. 36.

[3] Xi Jinping: "Decisive victory to build a well-off society in an all-round way to win a great victory in socialism with Chinese characteristics in the new era - Report at the 19th National Congress of the Communist Party of China", People's Publishing House, March 2018, p. 13.

[4] Xi Jinping: "Decisive victory to build a well-off society in an all-round way to win a great victory in socialism with Chinese characteristics in the new era - Report at the 19th National Congress of the Communist Party of China", People's Publishing House, March 2018, p. 15.

[5] Xi Jinping: "Decisive victory to build a well-off society in an all-round way to win a great victory in socialism with Chinese characteristics in the new era - Report at the 19th National Congress of the Communist Party of China", People's Publishing House, March 2018, p. 15.

[6] Xi Jinping: "Decisive victory to build a well-off society in an all-round way to win a great victory in socialism with Chinese characteristics in the new era - Report at the 19th National Congress of the Communist Party of China", People's Publishing House, March 2018, p. 11.

[7] Xi Jinping: "Decisive victory to build a well-off society in an all-round way to win a great victory in socialism with Chinese characteristics in the new era - Report at the 19th National Congress of the Communist Party of China", People's Publishing House, March 2018, p. 11.

[8] Program for Deepening the Reform of the Party and State Institutions, People's Publishing House, March 2018, p. 55. 